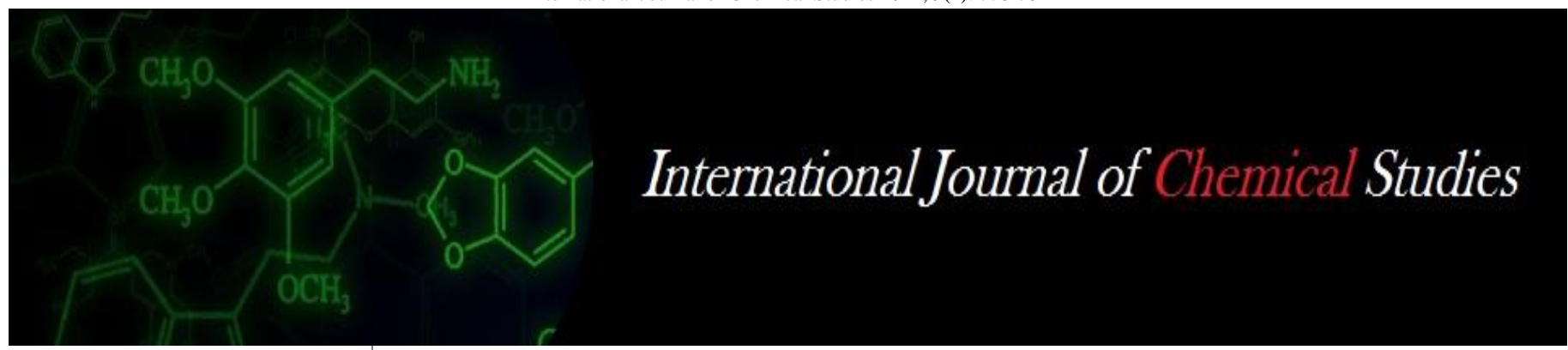

P-ISSN: 2349-8528

E-ISSN: 2321-4902

www.chemijournal.com

IJCS 2021; 9(1): 778-781

(C) 2021 IJCS

Received: 24-10-2020

Accepted: 02-12-2020

\section{Suhasini Jalawadi}

Assistant Professor, Department of Fruit Science, ICAR-AICRP

on Fruits, KRC. College of

Horticulture, Arabhavi,

Karnataka, India

\section{Dr. Jagadeesh RC}

Professor and Dean, Department of Biotechnology and Crop

Improvement, $\mathrm{COH}$, Bengaluru,

Karnataka, India

\section{Dr. Kantharaju V}

Professor and Head, Department of Plant Pathology, ICAR-

AICRP on Fruits, KRC. College

of Horticulture, Arabhavi,

Karnataka, India

\section{Dr. Basavaraj N}

Director of Research, UHS,

Bagalkot, Karnataka, India

\section{Dr. Nagesh Naik}

Professor and Head, Department

of Fruit Science, College of

Horticulture, Sirsi, Karnataka,

India

Dr. Sayeed Wajeed Mulla Assistant Professor, Department of Biotechnology and Crop Improvement, HRS, Tidagundi,

Vijayapur, Karnataka, India

\section{Evaluation of diploid banana genotypes under Northern dry zone of Karnataka}

\author{
Suhasini Jalawadi, Dr. Jagadeesh RC, Dr. Kantharaju V, Dr. Basavaraj \\ N, Nagesh Naik and Dr. Sayeed Wajeed Mulla
}

DOI: https://doi.org/10.22271/chemi.2021.v9.i1k.11319

\begin{abstract}
An experiment was conducted at ICAR-AICRP on Fruits, KRC. College of Horticulture, Arabhavi to study the evaluation of diploid banana genotypes under Northern dry zone of Karnataka during 2018-19. The results revealed that, among AA group, Namarai has taken minimum days to shooting (247.37 days) and in $\mathrm{AB}$ group, Kunnan has taken minimum days to shooting (256.14 days). Maximum bunch weight and yield was recorded in Kadali $(11.17 \mathrm{~kg} /$ plant \& $34.46 \mathrm{t} / \mathrm{ha})$ respectively which was on par with Anaikomban (10.25 kg/plant \& $31.63 \mathrm{t} / \mathrm{ha})$ among AA group. While in AB group, Ney Poovan had recorded highest bunch weight and yield $(16.47 \mathrm{~kg} / \mathrm{plant} \& 50.82 \mathrm{t} / \mathrm{ha})$. Whereas lowest bunch weight and yield was noticed in Namarai $(6.83 \mathrm{~kg} / \mathrm{plant} \& 21.08 \mathrm{t} / \mathrm{ha})$ in AA group, Aktoman $(8.13 \mathrm{~kg} / \mathrm{plant} \&$ $25.09 \mathrm{t} / \mathrm{ha}$ ) in $\mathrm{AB}$ group.
\end{abstract}

Keywords: Evaluation, diploid banana genotypes, growth, yield

\section{Introduction}

Banana (Musa paradisiaca L.) is a herbaceous, perennial, monocotyledonous and monocarpic plant belonging to the family Musaceae. It is known as apple of paradise. It has nutritional, medicinal and industrial value. Owing to its multifaceted uses, it is referred as Kalpataru (a plant of virtues). It is known throughout the tropical region of South-East Asia in pre-historic times. From its centre of origin in South-East Asia, it was introduced to all tropical and subtropical regions of world, where it gained great importance and popularity (Nasution and Yamada, 2001) ${ }^{[13]}$. India is considered as one of the important centre of diversity for banana, having about eight species and 120 clones. Out of these, lack of improved varieties is the critical problem to banana growers. Only few varieties are under cultivation in Karnataka along with commercial local cultivars. However, information on the performance of other cultivars (diploid banana genotypes) for growth, yield and quality characters in agro climatic condition of Northern dry zone of Karnataka (Zone-III) is lacking. Field evaluation of genotypes for growth and yield characters, and their suitability for fresh fruit or processing is a key factor for selection and further multiplication of promising genotypes and there by improve the crop productivity. Thus, it necessitates a suitable study to identify the high yielding genotype under northern dry zone of Karnataka. With this background the present investigation was carried out with ten diploid banana genotypes and observed for growth parameters as well as the yield components.

\section{Materials and Methods}

The investigation on "Evaluation of diploid banana genotypes under Northern dry zone of Karnataka" was carried out during 2018-19. Ten diploid banana genotypes of two different genomic groups (AA \& AB) viz., Anaikomban (AA), Cultivar Rose (AA), Kadali (AA), Namarai (AA), Pisang Lillin (AA), Aktoman (AB), Kodappanilla (AB), Kunnan (AB), Mitli $(A B)$ and Ney Poovan $(A B)$ were used for evaluation. The experiment was laid out in Randomized Complete Block Design (RCBD) with five replications and plants were spaced at $1.8 \times 1.8 \mathrm{~m}$ and results were tested at five per cent level of significance by using Fischer's method of analysis of variance as suggested by Cochran and Cox (1957) ${ }^{[5]}$. The observations on vegetative growth parameters were recorded at shooting stage. Pseudostem height was measured by taking length from base of pseudostem upto bifurcation of leaves and expressed
Corresponding Author: Suhasini Jalawadi Assistant Professor, Department of Fruit Science, ICAR-AICRP on Fruits, KRC. College of Horticulture, Arabhavi, Karnataka, India 
in meters. Pseudostem girth was measured at $5 \mathrm{~cm}$ above the ground level using tape and expressed in centimeters. The functional leaves were counted from each tagged plant at shooting stage. The leaf area was calculated by multiplying the leaf length and breadth with a correction factor 0.80 to arrive at the actual leaf area (Hewitt, 1955) [11]. Banana bunches were harvested when fingers were fully developed at 75 per cent maturity, angles with less prominent and fingers in hand started to change their color from dark green to light green. The bunch characteristics were recorded at the time of harvest of bunches. Five bunches in each genotypes were selected for recording bunch characters. Bunch length was measured by using meter scale from the first hand at the proximal end upto last hand at the distal end, mean length of bunches were recorded and expressed in centimeters. Bunch width was measured by using meter scale at the center of the bunch and mean width of bunches were recorded and expressed in centimeters. Actual number of hands in a bunch was physically counted and average number of hands per bunch was worked out. The total number of fingers per bunch were counted and recorded and the total number of fingers in third hand from top of the bunch were counted and recorded. Bunch weight of individual plant was measured using weighing balance and average was worked out and expressed in kilogram per plant. Yield per plant was calculated and plant population per hectare multiplied with yield, which resulted in yield (t/ha).

\section{Result and Discussion}

It is evident from the data (Table 1) that significantly maximum pseudostem height was recorded in Kadali (2.34 m) which was on par with Anaikomban $(2.00 \mathrm{~m})$ among AA group. In $\mathrm{AB}$ group, maximum pseudostem height was noticed in Ney Poovan $(2.29 \mathrm{~m})$ which was on par with Mitli $(2.25 \mathrm{~m})$ and lowest pseudostem height was recorded in Kodappanilla $(1.86 \mathrm{~m})$. This might be due to it's genetical characters. Similar findings were obtained by Devi et al. (2011) ${ }^{[8]}$. Medhi (1994) ${ }^{[12]}$ found that pseudostem height was significantly more in Athiakal cultivar. Kadali recorded maximum pseudostem girth $(56.20 \mathrm{~cm})$ which was on par with Anaikomban $(48.15 \mathrm{~cm})$ probably the plant height was contributed to the plant girth. whereas, lowest girth was noticed in Pisang Lillin $(23.26 \mathrm{~cm})$ among AA group. Among AB group, Ney poovan has recorded maximum pseudostem girth $(59.94 \mathrm{~cm})$ which was on par with Mitli $(58.36 \mathrm{~cm})$. These results are in line with Devi et al. (2011) ${ }^{[8]}$. Biswal et al. (2004) ${ }^{[4]}$ observed that girth of the pseudostem at the base was greatest $(88.66 \mathrm{~cm})$ in Batisha Bantala. The highest functional leaves per plant and maximum leaf area was recorded in Kadali $\left(10.41 \& 9.24 \mathrm{~m}^{2}\right)$ which was followed by Anaikomban $\left(9.31 \& 8.31 \mathrm{~m}^{2}\right)$ among AA group. In $\mathrm{AB}$ group, Ney Poovan has recorded more number of functional leaves (12.64) at shooting stage which was on par with Aktoman (12.14) whereas, maximum leaf area was observed in Kunnan $\left(9.18 \mathrm{~m}^{2}\right)$ which was followed by Ney Poovan $\left(8.46 \mathrm{~m}^{2}\right)$. These results were in accordance with Biswal et al. (2004) ${ }^{[4]}$. Number of leaves was highest in Borjahajee followed by Malbhog banana (Medhi, 1994) ${ }^{[12]}$. Among AA group, Namarai has taken minimum days to shooting (247.37 days) and in $\mathrm{AB}$ group, Kunnan has taken minimum days to shooting (256.14 days) while, minimum days to maturity was registered in Kadali (106.00 days) in AA group and Ney Poovan (120.76 days) in AB group. With regard to total crop duration, Kadali has harvested earlier (3358.82 days) which was on par with Namarai (360.49 days) among AA group while, in AB group, Mitli was harvested earlier (400.96 days) which was on par with Kodappanilla (405.22 days). The present results confirmed the report of Patel et al. (2011) ${ }^{[16]}$, Rajmanickam and Rajmohan (2010) ${ }^{[18]}$, Hazarika and Ansari (2010) [10], Uazire et al.(2008) [22], Rajamanickam et al. (2007) [17], Badgujar et al. (2004) [2], Orellana (2002) ${ }^{[15],}$ Sirisena and Senanayake (2000) ${ }^{[20]}$.

The yield attributing characters varied significantly among the genotypes which are presented in Table 2. Significantly maximum bunch length and bunch width was noticed in Kadali (47.30 \& $36.20 \mathrm{~cm})$ which was followed by Anaikomban (45.24 \& $31.23 \mathrm{~cm})$ among AA group while, in AB group, Kodappanilla recorded significantly maximum bunch length and bunch width $(49.56 \& 34.20 \mathrm{~cm})$ which was followed by Ney Poovan (47.90 \& $34.13 \mathrm{~cm})$ however, minimum bunch length and width was noticed in Aktoman ( $31.25 \& 25.04 \mathrm{~cm}$ respectively). In regard to the number of hands per bunch data preformed that, there were significant differences between genotypes. However, number of hands was significantly greater in Kadali (10.50) which was followed by Cultivar Rose (8.50) among AA group. In AB group, more number of hands were noticed in Kodappanilla (9.27) which was on par with Ney Poovan (8.65). These results are in agreement with Abdalla and Mohamed (2004) ${ }^{[1]}$, Oliveirae et al. (2006) ${ }^{[14]}$, Rayan et al. (2016) ${ }^{[19]}$ and Villalobos et al. (2004) ${ }^{[23]}$. Significantly Kadali has recorded more number of fingers per bunch (115.38) which was followed by (98.52) in AA group. However, in AB group, Ney Poovan has observed more number of fingers per bunch (125.40) which was followed by Aktoman (104.16) among $\mathrm{AB}$ group. With respect to bunch weight and yield, significant differences were observed among $\mathrm{AA}$ and $\mathrm{AB}$ genotypes. Maximum bunch weight and yield was recorded in Kadali $(11.17 \mathrm{~kg} /$ plant \& $34.46 \mathrm{t} / \mathrm{ha})$ respectively which was on par with Anaikomban $(10.25 \mathrm{~kg} /$ plant \& 31.63t/ha) respectively among AA group. While in AB group, Ney Poovan had recorded highest bunch weight and yield $(16.47 \mathrm{~kg} / \mathrm{plant} \&$ $50.82 \mathrm{t} / \mathrm{ha})$ respectively which was followed by Mitli (14.00 $\mathrm{kg} / \mathrm{plant} \& 43.20 \mathrm{t} / \mathrm{ha}$ ) respectively. This might be due to more plant girth, more number of leaves helped in enhanced photosynthesis and accumulation of food, more number of hands per bunch and number of fingers per bunch compactness of bunch led to increased yield. Whereas lowest bunch weight and yield was noticed in Namarai $(6.83 \mathrm{~kg} / \mathrm{plant}$ \& $21.08 \mathrm{t} / \mathrm{ha})$ in AA group, Aktoman $(8.13 \mathrm{~kg} /$ plant \& 25.09 $\mathrm{t} / \mathrm{ha}$ ) in $\mathrm{AB}$ group. Similar findings were obtained by Deshmukh et al. (2004) [7], Medhi (1994) ${ }^{[12]}$, Biswal et al. (2004) ${ }^{[4]}$, Gaidashova et al. (2008) [9], Deo et al. (1999) [6], Baruah et al. (2007) ${ }^{[3]}$ and Suvittawat et al. (2014) ${ }^{[21]}$.

Table 1: Growth parameters of different diploid genomic group of banana genotypes

\begin{tabular}{|c|c|c|c|c|c|c|c|}
\hline Genotypes & $\begin{array}{c}\text { Pseudostem } \\
\text { height }(\mathbf{c m})\end{array}$ & $\begin{array}{c}\text { Pseudostem girth } \\
(\mathbf{c m})\end{array}$ & $\begin{array}{c}\text { Functional leaves per } \\
\text { plant (Number) }\end{array}$ & $\begin{array}{c}\text { Leaf area } \\
\left(\mathbf{m}^{\mathbf{2}}\right)\end{array}$ & $\begin{array}{c}\text { Days to shooting } \\
(\mathbf{d a y s})\end{array}$ & $\begin{array}{c}\text { Days to maturity } \\
(\mathbf{d a y s})\end{array}$ & $\begin{array}{c}\text { Crop duration } \\
(\mathbf{d a y s})\end{array}$ \\
\hline \multicolumn{7}{|c|}{ AA Group } \\
\hline Anaikomban & 2.00 & 48.15 & 9.31 & 8.31 & 252.65 & 156.03 & 408.68 \\
\hline Cultivar Rose & 1.43 & 32.55 & 7.34 & 5.06 & 335.01 & 143.44 & 478.45 \\
\hline Kadali & 2.31 & 56.20 & 10.41 & 9.24 & 252.83 & 106.00 & 358.82 \\
\hline
\end{tabular}




\begin{tabular}{|c|c|c|c|c|c|c|c|c|}
\hline Namarai & 1.34 & 39.61 & 8.08 & 5.18 & 247.37 & 113.12 & 360.49 \\
\hline Pisang Lillin & 1.94 & 23.26 & 8.65 & 5.41 & 256.48 & 127.32 & 383.79 \\
\hline Mean & 1.80 & 39.95 & 8.76 & 6.64 & 268.87 & 129.18 & 398.05 \\
\hline S.Em \pm & 0.20 & 0.51 & 0.21 & 0.25 & 1.25 & 1.08 & 2.15 \\
\hline C.D@ 5\% & 0.74 & 1.61 & 0.65 & 0.75 & 3.84 & 3.21 & 5.34 \\
\hline C.V. & 10.96 & 4.21 & 4.31 & 5.24 & 4.21 & 3.51 & 3.56 \\
\hline \multicolumn{7}{|c|}{ AB Group } \\
\hline Aktoman & 1.97 & 48.90 & 12.14 & 5.98 & 297.79 & 128.05 & 425.84 \\
\hline Kodappanilla & 1.65 & 49.32 & 10.51 & 8.36 & 269.45 & 135.83 & 405.22 \\
\hline Kunnan & 1.86 & 45.33 & 11.40 & 9.18 & 256.14 & 155.49 & 411.63 \\
\hline Mitli & 2.25 & 58.36 & 11.75 & 8.38 & 276.40 & 124.56 & 400.96 \\
\hline Ney Poovan & 2.29 & 59.94 & 12.64 & 8.46 & 336.15 & 120.76 & 457.01 \\
\hline Mean & 2.00 & 52.37 & 11.68 & 8.07 & 287.18 & 132.93 & 420.13 \\
\hline S.Em \pm & 0.06 & 0.56 & 1.10 & 1.31 & 1.68 & 1.03 & 2.26 \\
\hline C.D@ 5\% & 0.19 & 1.68 & 1.51 & 1.79 & 4.96 & 3.05 & 6.66 \\
\hline C.V. & 7.28 & 2.43 & 7.19 & 7.36 & 1.31 & 1.74 & 1.20 \\
\hline
\end{tabular}

Table 2: Yield parameters of different diploid genomic group of banana genotypes

\begin{tabular}{|c|c|c|c|c|c|c|c|}
\hline Genotypes & \begin{tabular}{|c|}
$\begin{array}{c}\text { Bunch length } \\
(\mathrm{cm})\end{array}$ \\
\end{tabular} & \begin{tabular}{|c|} 
Bunch \\
width $(\mathrm{cm})$
\end{tabular} & $\begin{array}{c}\text { Number of hands per } \\
\text { bunch (number) }\end{array}$ & $\begin{array}{c}\text { Fingers /bunch } \\
\text { (number) }\end{array}$ & $\begin{array}{c}\text { No. of fingers in 3rd } \\
\text { hand (number) }\end{array}$ & $\begin{array}{c}\text { Bunch weight } \\
\text { (kg/plant) }\end{array}$ & $\begin{array}{l}\text { Yield } \\
(\mathrm{t} / \mathrm{ha})\end{array}$ \\
\hline \multicolumn{8}{|c|}{ AA Group } \\
\hline Anaikomban & 45.24 & 31.23 & 8.43 & 98.52 & 8.61 & 10.25 & 31.63 \\
\hline Cultivar Rose & 35.88 & 29.50 & 8.50 & 69.60 & 8.81 & 9.50 & 29.32 \\
\hline Kadali & 47.30 & 36.20 & 10.50 & 115.38 & 11.50 & 11.17 & 34.46 \\
\hline Namarai & 24.65 & 22.00 & 6.47 & 84.17 & 14.03 & 6.83 & 21.08 \\
\hline Pisang Lillin & 32.13 & 25.13 & 7.85 & 59.62 & 9.54 & 8.58 & 26.49 \\
\hline Mean & 37.04 & 28.81 & 8.35 & 85.46 & 10.50 & 9.27 & 28.60 \\
\hline S.Em \pm & 0.68 & 0.44 & 0.25 & 0.68 & 0.38 & 0.38 & 0.89 \\
\hline C.D@ 5\% & 1.89 & 1.89 & 1.20 & 2.04 & 0.98 & 0.94 & 2.67 \\
\hline C.V. & 4.56 & 4.95 & 5.84 & 3.65 & 6.84 & 6.51 & 6.21 \\
\hline \multicolumn{8}{|c|}{ AB Group } \\
\hline Aktoman & 31.25 & 25.04 & 8.00 & 104.16 & 12.30 & 8.13 & 25.09 \\
\hline Kodappanilla & 49.56 & 34.13 & 9.27 & 87.54 & 9.54 & 13.53 & 41.75 \\
\hline Kunnan & 41.53 & 32.62 & 8.56 & 95.61 & 10.03 & 12.00 & 37.03 \\
\hline Mitli & 43.90 & 32.20 & 8.20 & 89.96 & 12.81 & 14.00 & 43.20 \\
\hline Ney Poovan & 47.90 & 34.20 & 8.65 & 125.40 & 14.51 & 16.47 & 50.82 \\
\hline Mean & 42.82 & 31.63 & 8.53 & 100.53 & 11.83 & 12.82 & 39.58 \\
\hline S.Em \pm & 0.19 & 0.27 & 0.13 & 0.80 & 0.17 & 0.20 & 0.63 \\
\hline C.D@ $5 \%$ & 0.58 & 0.82 & 0.39 & 2.38 & 0.51 & 0.60 & 1.85 \\
\hline C.V. & 1.04 & 1.97 & 3.51 & 1.79 & 3.32 & 3.56 & 3.56 \\
\hline
\end{tabular}

\section{Conclusion}

Keeping the higher productivity in view, among diploid banana genotypes viz., Kadali (AA), Anaikomban (AA), Ney Poovan (AB) and Mitli (AB) can be recommended for commercial cultivation in Northern dry zone of Karnataka.

\section{Acknowledgement}

I am very much thankful to ICAR-AICRP on Fruits, KRC. College of Horticulture, Arabhavi for providing the necessary networking and coordination and also providing the materials for evaluation of bananan genotypes. Thanks also go to my guide Dr. Jagadeesh R. C. Dean, College of Horticulture, Bengaluru and all the committee members for their guidance during the course of investigation.

\section{References}

1. Abdalla BM, Mohamed SG. Comparative study on growth and fruiting of Williams, Grand Nain and Hindi cultivars of banana grown under Upper Egypt conditions. Assiut. J Agric. Sci 2004;35(1):270-278.

2. Badgujar C, Dusane SM, Desmukh S. Influence of plant spacing on growth, maturity and yield of Grand Naine (AAA) banana. South Indian Hort 2004;52(1-6):13-17.

3. Baruah K, Jyothi BS, Debajit S. Genetic variability in banana cultivars under Assam conditions. Indian Journal of Horticulture 2007;64(3):282-85.
4. Biswal MK, Lenka PC, Dash DK. Evaluation of culinary banana genotypes. Orissa. J Hort 2004;32(1):63-65.

5. Cochran, Cox. Experimental design procedure for the behavioral sciences. Cole Publ. Co 1957, 319-380.

6. Deo DD, Manohar VK, Sadawarte KT, Shelke BD, Growth. Yield performance of banana (Musa paradisiaca) types under Akola conditions. Agriculture Science Digest 1999;19:278-80.

7. Deshmukh SS, Badgujar CD, Dusane SM. Comparative evaluation of banana varieties under Jalgaon condition of Maharashtra state. Agric. Sci. Digest 2004;24:118-120.

8. Devi PS, Thangam M, Ladaniya MS, Korikanthimath VS. Evaluation of local banana cultivars under coconut shade in Goa. J Biol. Chem. Res 2011;28:63-76.

9. Gaidashova SV, Karemera F, Karamura EB. Agronomic performance of introduced banana varieties in lowlands of Rwanda (Uganda). African Crop Sci. J 2008;16(1):916.

10. Hazarika B, Ansari S. Effect of integrated nutrient management on growth and yield of banana cv. Jahaji. Indian J Hort 2010;67(2):270-273.

11. Hewit CW. Leaf analysis as a guide to the nutrition of bananas. Emp. J Exp. Agric 1955;23:11-16.

12. Medhi G. Performance of some cultivars of banana in Assam. Haryana J Hort. Science 1994;23(3):181-185. 
13. Nasution RE, Yamada I. Pisang-pisang liar di Indonesia [Wild bananas in Indonesia]. Bogor: Research Center for Biology-Indonesian Institute of Sciences 2001, 35-40.

14. Oliveirae SSD, Pires ET, Pestana RKN, Alves JDS, Silveira DDC. Evaluation of cavendish banana clones. Cienciae Agrotecnologia 2006;30(5):832-837.

15. Orellana P, Bermudez I, Rodriguez G, Rodriguez N. Evaluation of the agronomic characteristics of plantain hybrids (Musa spp.). INFOMUSA 2002;11(1):34-35.

16. Patel CM, Patel NL, Gaikwad SS, Patil SJ. Effect of post shooting treatments on yield and its attributes of banana cv. Grand Naine. Green Farming 2011;2(2):210-212.

17. Rajamanickam C, Rajmohan K, Parthiban S, Venkatesan K. Performance of triploid banana (Musa spp.) cultivars of Kerala. South Indian Hort 2007;55(1-6):119-132.

18. Rajamanickam C, Rajmohan K. Variability studies in Palayankodan ecotypes AAB genomic group of banana (Musa spp.). J Hort. Sci 2010;5(2):109-113.

19. Rayan AOH, El-Habashy S, Ahmed EAH. Evaluation of Two Banana Cultivars Produced from Meristem Culture in Comparison with Traditional Culture of Basrai under the Conditions of Sohag Governorate, Upper Egypt. American-Eurasian J Agric. \& Environ. Sci 2016;16(12):1764-1768.

20. Sirisena J, Senanayake SG. Estimation of variability parameters within Mysore banana clones and their implication for crop improvement. Scientia Hort 2000;84:49-66.

21. Suvittawat K, Silayoi B, Teinseree N, Saradhuldhat P, Growth and yield of eight Namwa (ABB) Banana in Thailand. Acta Horticulture 2014;1024:241-46.

22. Uazire A, Ribeiro C, Mussane R, Pillay M, Blomme G, Fraser $\mathrm{C}$ et al. Preliminary evaluation of improved varieties in Mozambique. African Crop Science $\mathbf{J}$ 2008;16(1):17-25.

23. Villalobos C, Perez L, Sandoval J. Vegetative and productive characterization of eight Cavendish banana cultivars (Musa AAA). CORBANA 2002, 2004;(55):1326. 